\section{Nature Conservation and}

\section{Human Well-Being in Bhutan}

\section{An Assessment of Local \\ Community Perceptions}

\author{
Chhewang Rinzin \\ Royal Institute of Management, Thimphu, Bhutan \\ Walter J. V. Vermeulen \\ Martin J. Wassen \\ Pieter Glasbergen \\ Utrecht University, Netherlands
}

(C) 2009 SAGE Publications

10.1177/1070496509334294

http://jed.sagepub.com

hosted at

http://online.sagepub.com

\begin{abstract}
Bhutan's nature conservation policy aims to integrate nature conservation and economic development. This policy is guided by a Buddhist attitude that places coexistence with nature over exploitation of nature for economic gain. We looked at how nature conservation policy affected everyday life and economic activities of local communities and what this may imply for the country's long-term socioeconomic development. The study includes a field survey involving 210 local residents in two national parks. The results indicated that there is support for nature conservation in local communities despite the significant restrictions on the use of non-timber forest products and the loss of crops to wild animals. However, the compensation schemes are inadequate which may lead to depopulation and the abandonment of land in rural areas.
\end{abstract}

Keywords: sustainable development; Buddhism; local communities; nature conservation; wildlife conflict; community-based conservation

$\mathrm{B}$ hutan has a strong nature conservation policy. This policy is firmly grounded in the principles of the country's development philosophy, which emphasizes the importance of achieving Gross National Happiness (GNH) over Gross Domestic Product (GDP), and the firmly established ethos of conservation in Buddhism. Conservation is the central tenet of Buddhism (see Royal Government of Bhutan [RGoB], 1996), which believes in preserving nature and the sanctity of life. As a result, the importance of protecting nature in all its manifestations has permeated Bhutanese consciousness and has become integrated into the Bhutanese value system. Due to economic globalization and a media boom, however, the Bhutanese are now increasingly exposed to the Western lifestyle. This is creating tensions between the state, civil society, and the market. The state imposes a strict conservation policy, whereas the market and the civil society strive for more material wealth. The challenge facing the policy maker is how to create a balance in the development process. To 
this end, an environmental strategy called the middle path strategy has been adopted, the aim of which is to bring about balanced development by avoiding extremes in materialism on the one hand and environmentalism on the other (see Rinzin, ten Velthuis, \& Vermeulen, 2007; Rinzin, Vermeulen, \& Glasbergen, 2007b).

The present study is premised on the hypothesis that conservation policy will be widely accepted in a Buddhist country even if it affects people's day-to-day economic activities. Our large-scale analysis tests this hypothesis and discusses the results in the context of the international debate on the effectiveness of different approaches to conservation in relationship to local communities. The aims of this article are to analyze

- how nature conservation policy is defined and implemented in Bhutan?

- how Buddhism influences the attitudes of local people toward nature conservation?

- the level of acceptance of nature conservation policy in local communities; and

- the effects of nature conservation policy on the economic activities of local communities.

Empirical research on the policy effects and public acceptance is fairly new in Bhutan. A comparable study on public acceptance reported opposition to the national park, but the scope of this study is very limited, missing an analysis of the conservation policy in practice (Wang, Lassoie, \& Curtis, 2006). This article presents results of the analysis of the implementation of conservation policies in Bhutan and links it to a broad public survey.

Before discussing the method and the results, we first discuss the position of Bhutan's specific approach in the context of the international discourse on nature conservation policies in developing countries.

Development-based nature conservation in developing countries has been a popular topic in the developed countries since the 1990s. Development assistance for these countries has therefore invariably included environmental and nature conservation programs. This conservation paradigm introduced the nature-society relationship (Abakerli, 2001) as an important step toward sustaining human well-being, that is, preserving and at the same time using natural resources.

Until fairly recently, a top-down approach was adopted toward conservation management, a legacy inherited from American and British colonial powers. The effects have been felt in African, Latin American, and Asian countries alike (Buergin, 2003; Colchester, 2004; Fraga, 2006; Ylhaisi, 2003). As a result, the conservation paradigm faces three problems in developing countries.

First, with its exclusionary models of land management through the establishment of "national parks," the conservation paradigm denied indigenous peoples their rights (Colchester, 2004). All too often, social, economic, and biological decisions in the overall development policy are taken with limited research and information (Dear \& Myers, 2005; Kamppinen \& Walls, 1999; Natori, Fukui, \& Hikasa, 2005; Pullin \& Knight, 2003; Slattery, 2002; Valutis \& Mullen, 2000). 
Second, the development of tourism has been a selling point for developing economies to commit to nature conservation programs. According to Abakerli (2001), this has deeply influenced environmental policies in developing countries and has become a source of tension between the need for local people to earn a livelihood and the management of protected areas (Abakerli, 2001; Christopoulou \& Tsachalidis, 2004; Roper, 2000).

The third problem lies in the failure to justify conservation on religious and cultural grounds rather than on purely economic or scientific ones. This has led to local people being sidelined when it comes to the management of protected areas (Sekhar, 2003). What is needed then is a strategy that could reduce the tension between the community and conservation management.

In African and South American countries, conservation is regarded as a secondary issue, with priority being given to poverty eradication. Negotiation with indigenous peoples therefore represents one of the most critical challenges for the long-term future of natural ecosystems in the region (Fearnside, 2003). The support of these peoples for conservation is minimal since it tends to hamper their traditional access to natural resources and is felt to undermine economic progress in the region (Huber, 2001). A number of case studies have indicated that conservation is perceived as a Western desire to maintain "pristine nature" in the developing world for tourism (Roper, 2000). Soto, Munthali, and Breen (2001) argue that in the context of today's world, conservation cannot be separated from human development and that where conservation does not take account of social and economic factors, it is doomed to failure. They further argue that, however, involving communities in policy formulation and management can promote successful conservation partnerships (Fraga, 2006; Soto et al., 2001).

Sentiment in South Asia, including China, is different from that in Africa and South America. According to Maikhuri, Nautiyal, Rao, and Saxena (2001), policypeople conflicts on conservation are as common in the Himalayas as elsewhere in the developing world, but vary enormously in terms of their nature and magnitude.

Case studies show that although people in China accept conservation policy, they regard economic development as more important. The main problem is the lack of control over economic activities around the protected areas due to population pressure, which renders parks incapable of achieving their intended goal (Yang \& Xu, 2003). Accordingly, in the Wolong Biosphere Reserve, local people claimed substantial compensation for loss of land for crops to forest protection and for higher electricity prices (Lin, Zhang, \& Chen, 2005; Yang \& Xu, 2003). Likewise, people in Mongolia, although they support nature protection, have shown no intention of reducing herd sizes or discontinuing grazing for the benefit of wildlife without compensation (Maroney, 2005).

Case studies in India reveal public support for the government's conservation policy, but conflicts have arisen over resettlement, restrictions on resource use, human/animal/crops conflicts, and inadequate compensation schemes (Mukherjee \& Board, 2004; Rao, Maikhuri, Nautiyal, \& Saxena, 2002; Rao, Nautiyal, Maikhuri, \& Saxena, 2003). 
In Nepal, although attitudes to conservation are generally positive, they are influenced by the way the people are treated (McLean \& Stræde, 2003). For instance, the attitudes of people living in and around parks and reserves managed by "fences and fines" are different from those of people in areas where the community-based conservation (CBC) approach is followed. People showed less regard for parks and reserves managed by the state where resource collection is allowed on a permit basis than for the CBC approach. This is because the resources are regarded as common property (Metha \& Heinen, 2001). According to Maroney (2005), these conflicts can be resolved by allowing local representation in management programs based on community involvement that provide direct benefits. Another way to engender local support is to implement Integrated Conservation and Development Projects (ICDPs) that meet the goals of the Convention on Biological Diversity (CBD) for sustainable use around the protected areas (Sekhar, 2003).

A survey by the World Wildlife Fund (WWF) of the effectiveness of the management of almost 200 protected areas in 34 countries concluded that a consistent problem has been the "failure to manage relations with people-local communities and indigenous peoples - and also the management of tourists" (WWF, 2004). In view of these problems, WWF International identified several challenges. The first was the question of how to develop a conservation policy which is based on the religious and cultural ethos of the local communities. The second challenge was to design an implementation strategy that guarantees the participation of the members of those communities. Last, there is the need to popularize nature conservation, making tourism development the key to socioeconomic development of the local community without threatening the local culture and the ecosystem.

These observations on the need for community involvement are very relevant in the context of Bhutan's unique ecological and societal situation. Situated on the vulnerable fringe of the Himalayan range, precocious management of its ecosystems is required. In addition, based on its Buddhist culture, Bhutan's government indeed introduced a rather unique sustainable development policy - the middle path strategy-aiming for gross national happiness (see, for a more detailed analysis, Rinzin, Vermeulen, et al., 2007). This strategy combines four so-called pillars of development, namely, sustainable and equitable economic development, ecological preservation, cultural preservation, and good governance. In this context, ICDPs were introduced as a means to achieve a balanced development. Yet some authors report unbalanced impacts. Wang, Curtis, and Lassoie (2006) report about farmers in the Jigme Singye Wangchuck National Park suffering major financial losses annually due to crop damage by wildlife.

In conclusion, we come to the following general description of the major issues. The developed economies prefer to conserve pristine nature for leisure. As there is no need to relocate local communities and there is no human-wildlife conflict, the general public rarely opposes the policies in their countries. By contrast, the majority of the population in developing countries still lives close to the natural world. The export of Western ideology, scientific knowledge, and management tools to the developing countries through development assistance creates an imbalance in the 
socioeconomic dynamics. In Africa and Amazonia, this raises the question of why nature conservation is necessary when basic human welfare is still lacking. Although this conflict may be less obvious in the Himalayan region, where the need for nature conservation is generally accepted, the question remains which nature protection approach fits in best with the religion and culture.

\section{Method}

To answer this question, we applied a mixed study, combining policy analysis with a survey on the perceptions and acceptation of conservation policies. This study was a part of a larger research project analyzing the implementation of Bhutan's sustainable development policy (see also Rinzin, 2006; Rinzin, ten Velthuis, et al., 2007; Rinzin, Vermeulen, et al., 2007).

To start with, we carried out a policy analysis, identifying policy maker's assumptions, targets, instruments, and the implementation practice. Data sources included encompassing published and unpublished reports, documents and workshop reports of the government. We also interviewed government officials in the nature conservation department, park managers and park rangers in the various field offices, and district administration officials. We also interviewed an expert at the nature conservation department who provided technical backstopping for park management at field level. Five park rangers and two district officials were interviewed.

To analyze the impacts for local people interviews, we conducted interviews with local park residents in July 2005. The interviewers were recruited on the basis of their experience and knowledge of the local language and culture. The research assistants, who were selected for the study, were trained in research methods and interviewing techniques for a week. The interviews were conducted simultaneously in two parks, the Jigme Dorji National Parks (JDNP) and the Thrumsingla National Park (TNP), using a structured questionnaire, after the first testing of the questionnaire. Lists of villages were prepared in advance in consultation with the park rangers to secure a representative sample of the views of people residing in and around the two parks. The respondents from these selected target groups were selected at random. For the survey of local people, one person was interviewed in each of 210 households in 8 of the 20 districts in the country.

Local people residing in parks are wary about giving information, and to collect information, the prior approval of the government is required. Accordingly, approval was requested from the Secretary of the Ministry of Agriculture, and once given, that consent was formally communicated to all district administrators, park managers, and rangers. Assistance was also requested through other formal channels wherever possible.

The data were processed using SPSS software and analyzed using basic descriptive statistical tools, that is, frequency and cross tabulations. When relevant, differences between the two parks were tested, using chi-square, with the two subsample sizes being $n=83$ and $n=127$. 


\section{Study Area}

\section{Bhutan}

Located in the Eastern Himalayas, Bhutan lies between two bio-geographical realms: the Palaearctic realm of temperate Euro-Asia and the Indo-Malayan realm of the Indian subcontinent. Bhutan provides a habitat for some 165 species of mammals, more than 700 species of birds, and at least 5,000 species of vascular plants. Although there are few endemic plant genera in the Eastern Himalayas, endemism is prevalent at the species and subspecies level. Consequently, by contrast with many countries, Bhutan has both significant endemism and high biodiversity (RGoB, 2001).

Forest covers $72 \%$ of Bhutan's total land area of $38,394 \mathrm{~km}^{2}$. The system of protected areas was established in the 1960s. The system was reviewed several times between 1983 and 1991 with the help of the WWF's Bhutan Program. The result is that Bhutan's protected area system covered approximately $26 \%$ of the country's total land area in the study period, ${ }^{1}$ with four national parks, one strict nature reserve, and four wildlife sanctuaries. A further $9 \%$ of the land area is designated as biological corridors. Six conservation areas have also been established for the conservation of specific species such as the black-necked crane, the white belly heron, and the tiger.

\section{Two National Parks}

Study Area 1: JDNP. The JDNP, covering an area of 4,393 $\mathrm{km}^{2}$, was established in 1974 and is the largest of the four major national parks in Bhutan. It is located in the western part of the kingdom at $27^{\circ} 35^{\prime}$ to $28^{\circ} 12^{\prime} 30^{\prime \prime} \mathrm{N}$ and $89^{\circ} 16^{\prime}$ to $90^{\circ} 17^{\prime} \mathrm{E}$ and lies at altitudes ranging from 1,400 to 7,000 meters above sea level (Figure 1). The northern boundary of the conservation area coincides with the border between Bhutan and China. The area covers the administrative jurisdictions of four districtsParo, Thimphu, Gasa, and Punakha. The JDNP represents an important reserve of alpine glaciers, meadows and scrub lands, alpine and subalpine conifer forest, warm and cool temperate broad-leaf forest, rivers and streams, and the flora and fauna which constitute these ecosystems. Particular species of wildlife for which the park provides a home include blue sheep, takins, bears, musk deer, marmots, red panda, and several species of pheasants. It is also a refuge for species which are threatened or endemic to the region, such as the tiger and the snow leopard.

Around 6,500 people, comprising about 651 households, live within the JDNP (RGoB, Nature Conservation Division, 2002). These local communities are directly or indirectly dependent on the resources in the park for their livelihoods. The economic activities of the population are park pastoralism in the north and subsistence farming in the south (Table 1). Households in the north depend on trading and selling yak produce in exchange for rice, chili peppers, salt, tea leaves, sugar, clothing, and other amenities, whereas the communities living in the south of the park derive most of their livelihood from agriculture and contract labor. 


\section{Figure 1}

\section{Study Areas: Jigme Dorji National Park (JDNP) and Thrumsingla National Park (TNP)}

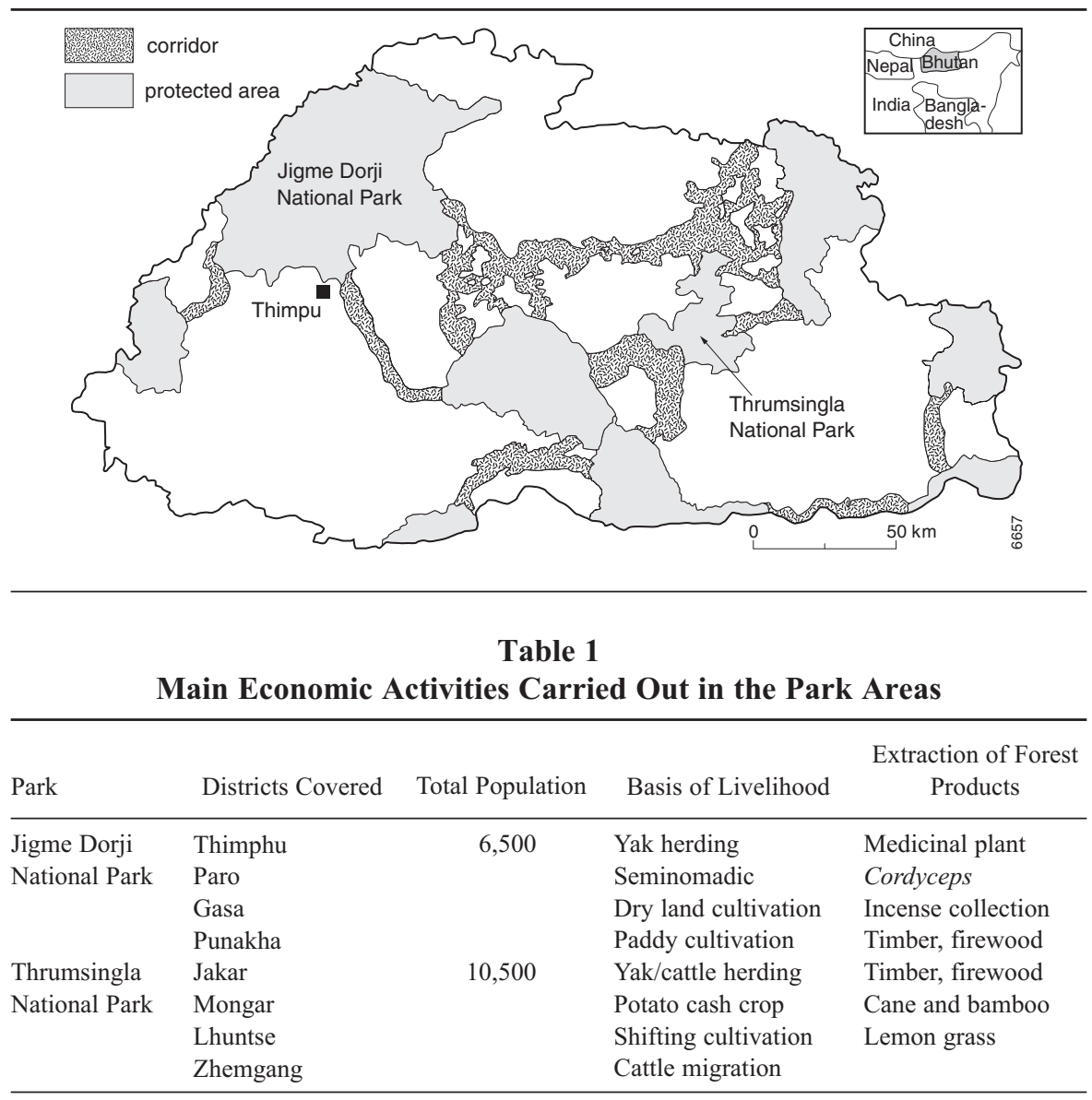

Study Area 2: TNP. The TNP was established in 1998. It lies at $27^{\circ} 12^{\prime} \mathrm{N}$ and $90^{\circ} 44^{\prime}-91^{\circ} 12^{\prime} \mathrm{E}$ and covers an area of $768 \mathrm{~km}^{2}$ (Figure 1). Its elevation ranges from 1,000 to $4,000 \mathrm{~m}$ above sea level. The park is located at the centre of four districts in the eastern and central region of the country-Bumthang, Zhemgang, Lhuntse, and Mongar. The park is regarded as special as it combines all the different vegetation zones in Bhutan and contains 21 species that are endemic to Bhutan. Some 68 species of mammals are known to exist in the park. Tigers are found at altitudes between 2,840 and $4,000 \mathrm{~m}$. Some 341 species of birds, including globally threatened rare birds, are also known to occur around the park. 
Some 10,500 people live in communities in four districts in and around the park. These communities subsist mainly on farming and livestock rearing. There is yearround cattle's grazing inside the park. Shifting agriculture is heavily practiced in these areas, which are also known for producing local artifacts from cane and bamboo (Table 1).

\section{Results A: Policy Analysis}

The government's overall policy objective for biodiversity conservation is to integrate nature conservation into economic development plans, with an emphasis on communities living within the protected areas and the buffer zones. The present analysis gives a brief background of the nature conservation policy, park management system, and the existing rules and regulations.

Since the Forest Act of 1969, the basis of Bhutanese policies and laws pertaining to conservation have progressed from forest-based land management to sustained yield principles and approaches. The 1969 Forest Act focused on traditional forest protection and introduced user permits. The revised 1991 Forest Act recognized the need for systematic management of conservation areas and to consider the economic needs of the local communities living in and around the conservation areas. This Act declared all nonprivate forest land to be government-owned forest reserves. In 1995, the National Assembly decreed that $60 \%$ of the country would remain under forest cover for all time. The amended Forest and Nature Conservation Act of 1995 therefore mandated the establishment of protected areas and the management system. The act also requires that the conservation of biodiversity should be guided by conservation values and should benefit the Bhutanese people. Over the years, the government has issued several acts, regulations, and orders, which provide the legal framework for the measures taken by the park managements to achieve the conservation goals.

Each national park prepared management plans based on the legislation. The basic park management plans include three management tools - zoning of park areas, law enforcement, and ICDPs (RGoB, 2003). Park areas are zoned to demarcate different zones with the aim of developing ecologically and economically viable land use in the park and the adjoining areas, protecting wildlife and their habitats in the parks, and meeting the needs of the resident communities without adversely affecting the ecosystems of the park. The zoning system includes core zones, multiple-use zones, and buffer zones. The restrictions in effect vary from one zone to another (Table 2). Core zones are fully protected areas, and no human-related use is permitted. Multiple-use zones are designated areas within protected areas where the aim is to encourage prudent socioeconomic development for the local community and normal farming activities are allowed. These zones also include areas for settlement, agriculture, visitors, forest utilization, and grazing. Buffer zones are areas established to provide an additional layer of protection at the periphery of protected areas, where restricted or regulated use of natural resources is permitted. 
Table 2

\section{Basic Protection Regimes for Various Zones Based on the Forest and Nature Conservation Rules}

\begin{tabular}{|c|c|c|c|}
\hline \multirow[b]{2}{*}{ Activity } & \multicolumn{3}{|c|}{ Restrictions Within Each Zone } \\
\hline & Core Zone & $\begin{array}{l}\text { Multiple Use Zone } \\
\text { (Within Park) }\end{array}$ & $\begin{array}{l}\text { Buffer Zone and Corridors } \\
\text { (Outside Park Boundaries) }\end{array}$ \\
\hline $\begin{array}{l}\text { Construction of any } \\
\text { nature }\end{array}$ & No & Yes, but only with permit & $\begin{array}{l}\text { Yes, but not allowed in } \\
\text { Government forest }\end{array}$ \\
\hline $\begin{array}{c}\text { Settlement or } \\
\text { cultivation }\end{array}$ & No & Yes, but only with permit & Yes \\
\hline Commercial logging & No & No & $\begin{array}{l}\text { Yes, after consultation } \\
\text { with park }\end{array}$ \\
\hline $\begin{array}{l}\text { Noncommercial } \\
\text { logging }\end{array}$ & No & Yes, but only with permit & Yes, with permit \\
\hline Grazing & $\begin{array}{l}\text { No, except in case of } \\
\text { traditional right } \\
\text { and management } \\
\text { plan is not violated }\end{array}$ & $\begin{array}{l}\text { Yes, but only within } \\
\text { designated area }\end{array}$ & $\begin{array}{l}\text { Yes, but may be regulated } \\
\text { in Government reserved } \\
\text { forest }\end{array}$ \\
\hline $\begin{array}{l}\text { Firewood } \\
\quad \text { collection-dry }\end{array}$ & No & $\begin{array}{l}\text { Yes, but only for local } \\
\text { resident for domestic } \\
\text { use }\end{array}$ & Yes, from nearby forest \\
\hline $\begin{array}{l}\text { Firewood } \\
\quad \text { collection-wet }\end{array}$ & No & Yes, with permit & Yes, with permit \\
\hline Social forestry & No & $\begin{array}{l}\text { Yes, but community } \\
\text { forest only, otherwise } \\
\text { with permit }\end{array}$ & Yes, after registration \\
\hline Research & $\begin{array}{l}\text { Yes with permit and } \\
\text { in the management } \\
\text { plan }\end{array}$ & $\begin{array}{l}\text { Yes with permit and } \\
\text { contemplated by mgt } \\
\text { plan }\end{array}$ & $\begin{array}{l}\text { Yes, but may be regulated } \\
\text { in Government reserved } \\
\text { forest }\end{array}$ \\
\hline Taking wildlife & No & Yes, but only with permit & $\begin{array}{l}\text { Yes, only in crop } \\
\text { protection }\end{array}$ \\
\hline Fishing & No & $\begin{array}{l}\text { Yes, but only with permit } \\
\text { and in designated } \\
\text { fishing zone }\end{array}$ & Yes, but only with permit \\
\hline $\begin{array}{l}\text { Extraction of soil, } \\
\text { stone, sand, mud- } \\
\text { for domestic use }\end{array}$ & No & $\begin{array}{l}\text { Yes, within } 2 \mathrm{~km} \text { radius } \\
\text { of user resident }\end{array}$ & $\begin{array}{l}\text { Yes, within } 2 \mathrm{~km} \text { radius of } \\
\text { user resident }\end{array}$ \\
\hline $\begin{array}{l}\text { Extraction of soil, } \\
\text { stone, sand, mud- } \\
\text { for commercial use }\end{array}$ & No & $\begin{array}{l}\text { Yes, within } 50 \text { feet radius } \\
\text { of construction site } \\
\text { only }\end{array}$ & $\begin{array}{l}\text { Yes, but may be regulated } \\
\text { in Government reserved } \\
\text { forest }\end{array}$ \\
\hline $\begin{array}{l}\text { Miscellaneous } \\
\text { nontimber forest } \\
\text { products- } \\
\text { commercial }\end{array}$ & No & Yes & Yes \\
\hline $\begin{array}{l}\text { Miscellaneous } \\
\text { nontimber forest } \\
\text { products- } \\
\text { noncommercial }\end{array}$ & No & Yes, but only with permit & Yes, but only with permit \\
\hline
\end{tabular}


The conservation policy does not, however, allow the displacement of resident local communities from the park areas. Therefore, if there is a cluster of communities within the core zone, further zoning of land use within that zone will be required, followed by regulation and monitoring according to the rules and regulations for nature conservation. The concept of zoning tries to address specific local conditions, such as the existence of traditional rules on grazing rights or the communal use of forest, and to combine them with sustainable use of renewable resources. The recent Forest and Nature Conservation Rules shown in Table 2 set out the legal framework for implementing the management plans, which provides for a significant degree of decentralization, land-use planning, and the concept of management by zoning.

The ICDP program is employed as a development tool to enhance the socioeconomic potential of the local communities living in the park areas. The government's approach with this program is to consider the local communities as a partner in conservation rather than as a threat to conservation. The park management process itself entails the need to involve and empower the local people. The concept of ICDP is intended to fulfill the dual objectives of promoting socioeconomic development for people living within the park and supporting the government's biodiversity conservation efforts. The programs include the provision of development services, environmental education and awareness, enterprise development, and the like. The objective of the ICDP is therefore to encourage community participation through the following planning process:

- The ICDP must be integrated in district planning cycles;

- The detailed planning of ICDP activities is prepared and discussed first at the local development committee meeting;

- The plan is then submitted to the district development committee for further discussion and incorporation into the overall district development plan;

- The district administration is responsible for its implementation.

Summarizing, we can conclude that the national conservation policy increasingly aims for community participation in national parks management. This is remarkable in the light of the low acceptance of national parks, as reported by Wang, Lassoie, et al. (2006). To understand this, we need to have a better view on the experiences of the park inhabitants.

\section{Results B: Public Perceptions of the Policy and Its Impact on Their Lives}

A total of 210 local residents and 9 state officials in the two national parks were interviewed during this study. The results shown below represent the opinions of the local residents of the two parks. Wherever we found significant differences of 
opinions between the residents of the two parks, we have reported the findings separately (applying the chi-square with significance levels $<.01$ ). For comparison, the opinions of the state officials are also mentioned where appropriate.

\section{The Buddhist View of Nature Conservation}

As Table 3 illustrates, Buddhism has an influence on people's attitudes. A majority of the respondents among state officials $(62 \%)$ and in the local communities $(67 \%)$ confirmed that Buddhism has a significant influence on their lives. About $75 \%$ of the state officials and $71 \%$ of the local residents felt Buddhism had a major influence on their attitude toward nature conservation, whereas $25 \%$ of the state respondents and $27 \%$ of the local residents felt Buddhism had no influence at all. Furthermore, $53 \%$ of the local community mentioned the need to preserve sacred forest that had been inherited from their ancestors. These results are consistent with other studies (Rinzin, Vermeulen, et al., 2007). Respondents were also asked to comment on several statements about the importance of nature. A large majority (81\%) agreed that nature is an important source of food, whereas opinions on the exploitation of nature for income were equally strong favoring the use of natural resources, with $88 \%$ for and $12 \%$ against. Some $84 \%$ agreed that nature has its own inherent value.

\section{People's Perception of Nature Conservation Policy and Its Impact on the Way of Life}

In another study on the public perception of the middle path strategy, we registered an overwhelming support (97\%) for the government's nature conservation policy (Rinzin, Vermeulen, et al., 2007b, p. 60). Yet in this study, we saw that $15 \%$ of the respondents from the local communities in the JDNP do not support the conservation policy. A majority (78\%) of these respondents also said they were aware of the goal of nature conservation. Furthermore, $82 \%$ felt the conservation goals were properly communicated to them. Our results show a different tendency than the study by Wang, Lassoie, et al. (2006) in another Bhutanese national park, where $52 \%$ answered no to the question, "Do you like the park and its policy?" Yet these answers to their fairly general question can be understood if we look more into detail to the experiences of the park inhabitants.

In our study, $43 \%$ of the respondents felt the rules were strict and $32 \%$ considered them to be very strict, whereas $25 \%$ felt they were not strict (Table 4 ). About $52 \%$ of the respondents saw changes in the pattern of land use after the establishment of the park. Most respondents (61\%) saw the ban on community forest management including ownership and carrying on activities in forests and on shifting cultivation practices as the main causes of the change in land use. 
Table 3

The Influence of Buddhism on People's Attitudes

Toward Nature Conservation $(n=219)$

\begin{tabular}{|c|c|c|}
\hline & State $(n=9)$ & Local People $(n=210)$ \\
\hline Questions and Reactions & $\%$ & $\%$ \\
\hline \multicolumn{3}{|c|}{ How much is your life influenced by Buddhism? } \\
\hline Very much & 62.2 & 66.5 \\
\hline Some influence & 25.0 & 33.1 \\
\hline Not very much & 12.5 & 0.5 \\
\hline \multicolumn{3}{|c|}{ How much of your attitude toward nature conservation is attributable to Buddhism? } \\
\hline Positive & 75 & 71.4 \\
\hline Negative & - & 1.7 \\
\hline Neutral & 25 & 26.7 \\
\hline \multicolumn{3}{|c|}{ Are there any protected areas in your village that have been inherited from your ancestors? } \\
\hline Yes & & 53.3 \\
\hline No & & 21.0 \\
\hline Not applicable & & 25.7 \\
\hline \multirow{2}{*}{\multicolumn{3}{|c|}{$\begin{array}{l}\text { Do you agree with the following statements about nature? } \\
\text { a) Nature is important as a source of food }\end{array}$}} \\
\hline & & \\
\hline Fully agree & & 81.2 \\
\hline Agree to some extent & & 14.4 \\
\hline Do not agree & & 4.3 \\
\hline \multicolumn{3}{|c|}{ b) Nature is to be exploited for income } \\
\hline Fully agree & & 44.4 \\
\hline Agree to some extent & & 43.7 \\
\hline Do not agree & & 12.0 \\
\hline \multicolumn{3}{|c|}{$\begin{array}{l}\text { c) Nature is something valuable in its } \\
\text { own right }\end{array}$} \\
\hline Fully agree & & 84.1 \\
\hline Agree to some extent & & 15.3 \\
\hline Do not agree & & 0.5 \\
\hline
\end{tabular}

The opinion about changes in the amount of land under cultivation is mixed. In all, $45 \%$ of the respondents felt the amount of land under cultivation had declined, whereas $43 \%$ saw there was no change and $13 \%$ said it had increased. Cattle migration, a serious concern of the government, was by most residents not perceived to have changed in the parks, but about $20 \%$ of the respondents claimed movement was restricted completely after the introduction of new conservation rules and regulations. The history of shifting cultivation is insignificant in JDNP compared to TNP. In JDNP, people living in higher altitude are either nomadic or seminomadic, and those living in the lower altitude practice mostly wet-land cultivation, whereas in TNP, the shifting cultivation practice was very significant (RGoB, 2001, 2005a).

Opinions on the issues of land use and the effect of the rules and regulations on cattle migration differed significantly between the two national parks (Table 5). 
Table 4

People's Perception of and Support for Government Policy $(n=210)$

\begin{tabular}{lc}
\hline & Responses (\%) \\
\hline Do you think park management rules are & \\
Not strict & 25.4 \\
Strict & 42.9 \\
Very strict & 31.7 \\
Has there been a change in land use since the establishment of the park? & 52.2 \\
Yes & 47.8 \\
No & \\
If so, what are the changes? & 61 \\
Community forest and shifting cultivation practice disallowed & 17 \\
Government taking control of pasture land & 22 \\
Increased yield due to improved seed supplied & \\
Area of land under cultivation increasing or decreasing? & 12.9 \\
Increase & 44.8 \\
Decrease & 42.3 \\
Same as before & 3.8 \\
Did park establishment change traditional norms of cattle migration? & 20.0 \\
Changed to no movement & 76.2 \\
Restricted movement & \\
Same as before & \\
\hline
\end{tabular}

A significant majority (76\%) of the respondents in the TNP felt that land use had changed since the establishment of the park, compared to $24 \%$ of the respondents in JDNP. Furthermore, $59 \%$ of the respondents in the local communities in TNP felt there had been a decline in land use, whereas no significant changes appear to have been experienced in the JDNP. Respondents from the TNP more often felt that the cattle migration rules had affected their lives than the respondents from the JDNP.

\section{Socioeconomic Benefits and Cost of Nature Conservation to the Local Communities}

The government introduced ICDPs in the nature conservation areas with the goal of furthering the socioeconomic development of the local residents and thus reducing their dependence on the surrounding natural resources. Answers to our survey question ("Has the forest cover increased after the establishment of the park?") show that practically all respondents (99\%) felt there had been an increase in forest cover in recent years. We also asked, "In your opinion, how does the park affect your life as compared to before?" The results were that $35 \%$ answering their life is "most satisfactory" and $63 \%$ saying "satisfactory" since the area had been designated as a nature conservation area. Table 6 presents more specific results of responses with respect to ICDP activities. A majority of respondents reported significant improvements 
Table 5

People's Perception on the Impact of Park Rules

\begin{tabular}{lcc}
\hline & JDNP $(\%)$ & TNP (\%) \\
\hline Has there been a change in land use since the establishment of the park? & 13.23 & \\
Yes & 86.77 & 75.98 \\
No & 22.97 & 24.02 \\
Area of land under cultivation increasing or decreasing? & 14.95 \\
Increase & 28.38 & 50.88 \\
Decrease & 48.65 & 34.2 \\
Same as before & 2.43 & 2.97 \\
Did park establishment change traditional norms of cattle migration? & 26.56 \\
No movement & 7.23 & 70.47 \\
Restricted movement & 90.35 & \\
Same as before &
\end{tabular}

Note: Jigme Dorji National Park: $n=83$; Thrumsingla National Park: $n=127$; Chi-square $=87.265$, 43.034, 71.419, all $p=.000$.

Table 6

Opinion on the Benefits of Parks $(n=210)$

\begin{tabular}{lcr}
\hline & Yes & No \\
\hline Since the establishment of the park, have you seen improvement in & & \\
Education & 81.8 & 18.2 \\
Government subsidy for agriculture & 80.4 & 19.6 \\
Increase in quality of livestock & 78.5 & 21.5 \\
Increase in forest resources & 74.8 & 25.2 \\
Health facilities & 73.1 & 26.9 \\
Drinking water & 66.8 & 33.2 \\
Increase in extension service & 64.3 & 35.7 \\
Agriculture extension service & 53.7 & 46.3 \\
Electricity & 38.0 & 62.0 \\
Irrigation & 34.9 & 65.1 \\
Farm road & 29.6 & 70.4 \\
\hline
\end{tabular}

in a range of services: education (82\%), agriculture (80\%), animal husbandry $(79 \%)$, and health $(73 \%)$. The respondents also experienced improvements in forest resources $(75 \%)$ and water supply $(67 \%)$. However, services requiring a major capital investment, such as electricity, irrigation, and farm roads do appear to have improved by a lesser degree.

Further comparison of local people's opinions on the provision of farm roads, irrigation, and electricity (Table 7) reveals slight differences of opinion between the people living in one or the other of the parks. JDNP has benefited more from road development, whereas TNP has benefited more from irrigation and electricity. 
Table 7

Differences in Opinions on the Benefits of Parks:

Two Parks Compared $(n=210)$

\begin{tabular}{lcc}
\hline $\begin{array}{l}\text { Opinion on the Benefits } \\
\text { of Parks }\end{array}$ & Jigme Dorji National Park (\%) & Thrumsingla National Park (\%) \\
\hline $\begin{array}{l}\text { Farm road } \\
\text { Yes }\end{array}$ & 46.2 & 27.6 \\
$\quad$ No & 53.8 & 72.4 \\
Irrigation & & 45.7 \\
$\quad$ Yes & 39.4 & 54.3 \\
No & 60.6 & 41.2 \\
Supply of electricity & & 58.8 \\
$\quad$ Yes & 31.1 & \\
No & 68.8 & \\
\hline
\end{tabular}

Note: Chi-square $=86.78,89.945,41.485$, all $p=.000$.

We then surveyed the adverse effects of nature conservation activities on the well-being of the local communities. The results are shown in Table 8. A large majority of the respondents $(93 \%)$ felt the nature conservation rules restricted their use of timber and wood for fuel, whereas $75 \%$ of the respondents felt the harvest of non-timber forest products was also partially controlled by the government.

Table 9 shows the findings concerning the impact of wild animals on the local economy. Some $73 \%$ of the respondents felt that wild animals caused damage to crops; between one and four family members spent, on average, at least 4 months each year guarding their crops at night (mentioned by $71 \%$ ). Wild animals that caused damage to crops were deer, wild pigs, and monkeys (84\%), whereas bears $(42 \%)$ also caused damage to livestock, as did snow leopards, leopards, and tigers $(30 \%)$. The villagers were eligible for compensation for the loss of livestock to tigers or snow leopards, but it was only partially compensated (69\%), and 23\% said they did not receive any compensation at all. However, no compensation was available for crops destroyed by any kind of wild animal. The state respondents agreed on the incidence of wildlife depredation on crops and livestock, but $89 \%$ said the compensation scheme was only applicable to livestock depredation. This scheme was currently funded from the WWF tiger compensation scheme.

Analysis of the opinions of the respondents from the different parks shows that more respondents from TNP (93\%) than from JDNP (70\%) tend to believe that wild animals destroy crops.

Table 10 shows how the forest and nature conservation rules have affected the use of non-timber forest products in the perception of the inhabitants. These new rules imply that for domestic use, which are small quantities for personal use, one 
Table 8

Cost to the Local People as a Consequence of Nature

Conservation Areas (in Percentage; $n=210$ )

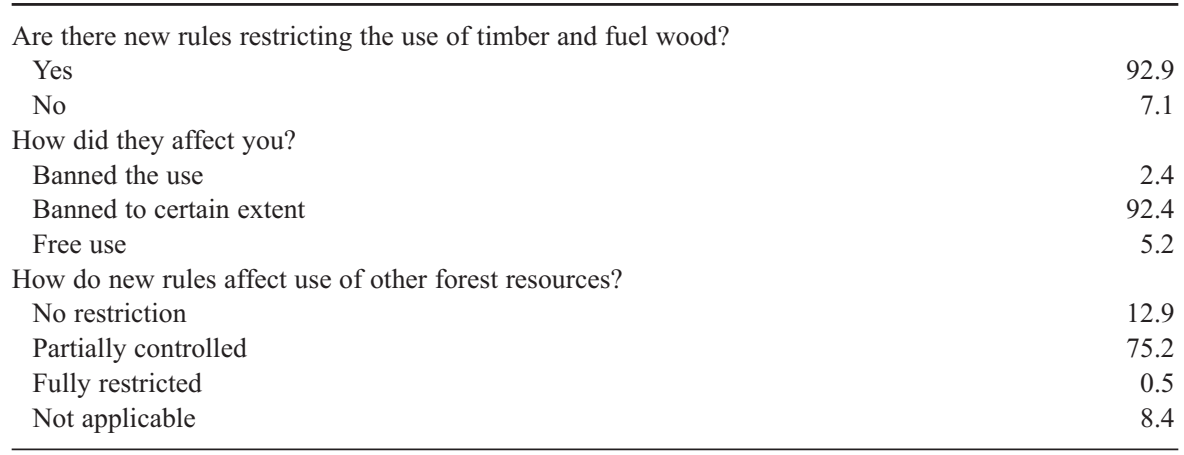

Table 9

Cost to People: Crop and Livestock Depredation

by Wild Animals (in Percentage; $n=210$ )

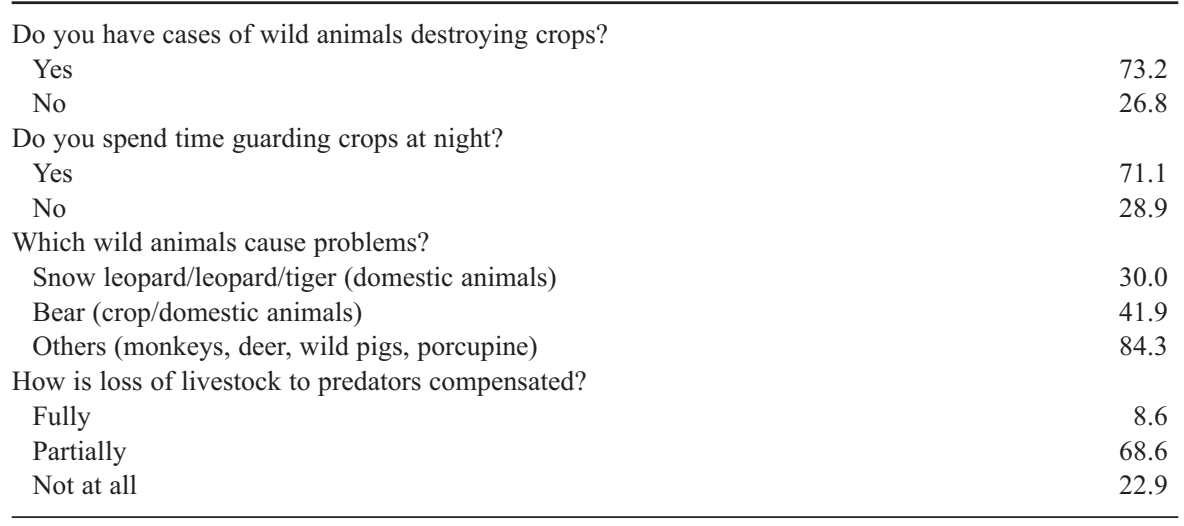

does not need to get a permit in the multiple use zones, and therefore it is free of costs. However, for commercial use, such as for sale on the market or supply in large quantities, one must get a permit from the forestry office, which has to be paid for. These rules appear to be not fully understood, as Table 10 shows. Harvest of non-timber forest products such as food for personal use was perceived as free by $75 \%$, whereas the free use for domestic purposes was often misunderstood as not being for free for the following products: fuel wood (70\%), medicinal herbs $(65 \%)$, and cane and bamboo (56\%). 
Table 10

Perceptions of Respondents Concerning Use of Certain

Nontimber Forest Products Free of Charge, for Payment or Being Unaware of Any Rules (See Table 2; $n=210$ )

\begin{tabular}{lccc}
\hline Nonforest Products & Free (\%) & For Payment (\%) & Not Applicable (\%) \\
\hline Food for personal use & 74.8 & 24.8 & 0.5 \\
Fuel wood for domestic use & 30.0 & 70.0 & 0.0 \\
Collection of medicinal herbs & 39.8 & 49.7 & 10.5 \\
Medicinal herbs for commercial use & 24.7 & 64.9 & 10.3 \\
Cane and bamboo for domestic use & 32.0 & 56.2 & 11.9 \\
Cane and bamboo for commercial use & 12.3 & 67.3 & 20.5 \\
\hline
\end{tabular}

\section{Impact on Local Art, Culture, and Property Ownership}

Table 11 reveals the impacts of the new rules on local arts and crafts. In the areas we surveyed, the local communities produced at least four kinds of arts and crafts. About $76 \%$ indicated that the park rules did not affect these arts and crafts. However, $24 \%$ of the respondents felt the permit system had adversely affected their work. According to $62 \%$ of the respondents, the new system ignored the traditional norms of resource management. Nevertheless, $69 \%$ of the people are still positive toward nature conservation policy.

As we showed in the beginning of this section, Bhutan's conservation policy enjoys strong support of the local communities, but we now discussed various discontents. According to Metha and Heinen (2001), one way of generating community support is through community-based development.

In general, this observed strong public support for the nature conservation policy in both national parks contradicts the results of the study by Wang, Curtis, et al. (2006). This can be explained by looking at the more detailed questioning in our study. To a certain extent, ICDP activities are responsible for achieving a high level of satisfaction, with increased benefits in education, health, agriculture, and animal husbandry extension services (Table 6). At the same time, these activities are seen as a source of tension.

Our interviews with district officials, park managers, and inhabitants of the park also showed that if ICDP is poorly managed, it can be a source of tension between the district officials, the park management, the local communities, and the wildlife. The district officials do not approve of direct implementation of ICDP activities by the park management. They feel that it is the responsibility of the districts, whereas the park managers feel they are better trained to deal with the public on sensitive conservation issues. Representatives of the park management, meanwhile, feel that local people expect them to do everything instead of getting involved in development activities themselves. In our interviews, they accused local people of being more 
Table 11

Impact on Local Culture and Traditions (in Percentage; $n=210$ )

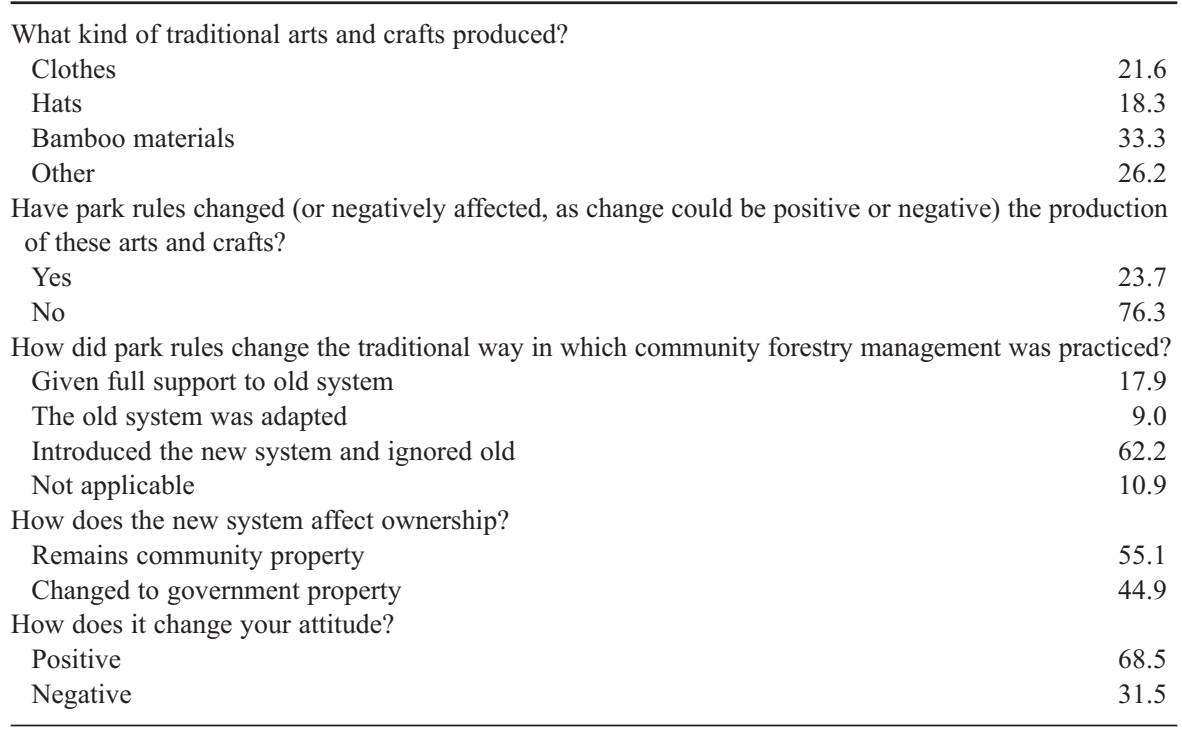

concerned about receiving their share of direct benefits like barbed wire, corrugated iron sheets (CGI), solar lights, and so on, whereas locals blame the conservation program for not providing electricity, irrigation, and the like.

We have to bear in mind that the present assessment describes the attitude of the local communities at a time when the implementation of nature conservation rules and regulations has been in operation for barely 2 years. Our visits to the park rangers' offices during this study indicated that the offices are newly established and are poorly staffed, with the result that the park rangers admitted that implementation of rules has not been effective. Similar studies in future would be able to establish whether people's perception of government policy and their attitudes toward nature conservation remain positive despite its negative impact on their lives. Changes in this respect could be a result of changing attitudes toward religion, economic well-being, and traditional rights.

What we see here is that the nature conservation policy as such has been hailed as good policy but that the practical implementation of the policy has been flawed. The government adopted an ICDP approach; in fact, JDNP was the first park to implement this practice, and in this respect it actually failed. In practice, the ICDP activities were developed in projects linked to foreign donors. One implication was that the involved mainstream development agents did not want ICDP activities to be carried out into the villages by the Department of Nature Conservation without incorporating into the Five Year Development Plan of the country. 


\section{Discussion}

\section{The Role of Buddhism in Attitudes to Conservation}

Basing conservation policy on religion and local culture can be an important source for success when working with the traditional local communities. Our present study explores how local communities perceive nature conservation rules and regulations from the perspective of Buddhist principles. The majority of the respondents among state officials and residents of local communities agreed that Buddhism had a major influence on their lives (66.5\% answering "very much influence" in Table 3). So, Buddhism seems to have a strong influence on attitudes toward nature conservation. Many local communities seem to respect traditional beliefs by preserving sacred forests. They consider the forest to be an important source of food but not as something to be exploited for economic gain. Most people also see it as a valuable source of spiritual health (84\%). This indicates people's close ties with nature as a provider of economic sustenance and spiritual well-being. It also indicates that Buddhism has some influence in shaping people's attitudes toward the environment.

Buddhism looks at nature differently than other religions (Palmer \& Bisset, 1989). For Buddhists, everything in this world is "impermanent," including material wealth. Buddhists believe that all lives are interconnected, and thus abstention from killing living creatures lies at the heart of Buddhist moral values. Another belief is the theory of "karma," the karmic cycle of birth and rebirth, the law of cause and effect. Buddhists believe that a person can be reborn in any form, for example, as a god or demigod in the upper realm or as a human or an animal, depending on the merits accumulated through virtuous deeds (Nelissen, Van Der Straaten, \& Klinkers, 1998; White, 1994). These virtues take the form of a gentle nonviolent attitude toward living creatures (Silva, 1992).

\section{Impacts on Traditional Rights, Use of Resources, and Attitudes to Conservation}

Nature conservation policy and park regulations in Bhutan have significant effects on the economic activities of the local communities. These regulations include the ban on shifting cultivation practices, community forestry management practices, and increasing government intervention to control pastureland and wildlife depredation of crops and domestic livestock. Some of these actions may be responsible for a decline in land use for agricultural cultivation (Table 4).

The implications of these findings must be understood in relationship to the local dependency on subsistence farming and the national economy. Recent figures show that agriculture contributed $26.2 \%$ to the total economy and provided a livelihood for $79 \%$ of the population in 2003 (Central Statistical Organisation, 2005). This contribution came from $7.7 \%$ of the land available for cultivation (RGoB, 2004). 
Shifting cultivation is practiced on $64 \%$ of the $7.7 \%$ of the land under cultivation; the ban on shifting cultivation could therefore have a significant impact on the local economy and also on the national economy, as the possibilities for agriculture are limited by nature conservation policy.

Restrictions on the use of forest resources and wildlife depredation of crops and domestic livestock have been the subject of international discussion, including various recent studies in the Himalayan region. Exclusion of people from the forest to protect biodiversity often antagonizes local communities (Arjunan, Holmes, Puyravaud, \& Davidar, 2006). Our study shows that in Bhutan, a large majority of the people feel that the use of timber, fuel wood, and other forest resources is controlled. Restrictions on these traditional user rights tend to increase competition for the limited resources during the season, while at the same time they tend to take less care of the resources as they feel they have become common property.

The present study revealed the government's disregard for the traditional norms of the local people. The nature conservation rules have ignored the traditional norms of resource management and introduced new rules (Table 11). The restrictions on the use of nontimber products also appear to have affected the production of traditional local artifacts. An earlier study on community forest management yielded similar results (Wangchuk, 2001). This may be attributable to a colonial-style, top-down approach to forestry management which is largely influenced by donor countries (Buergin, 2003; Colchester, 2004).

\section{Nomadic Pastoralist and Conservation Issues}

Cattle's herding in Bhutan is the principal economic activity of the seminomadic pastoralists living in the nature conservation areas (Table 5). In view of the fragility of the Himalayan mountain ecosystem, the migration of cattle and their intensive grazing pattern are a source of concern to the government (although grazing has been going on for centuries). Concerted efforts have been made to reduce the size of the herds in recent years. Recent studies on the impact of cattle grazing in the alpine and subalpine region have found that cattle grazing and seasonal migration pose a serious threat to the ecosystem due to overgrazing (Gyamtsho, 1996, 2002; Muradin, 2002; Norbu, 2002; Roder, 2002; Wangchuk, 2002). One of the reasons given was the lack of control of grazing at the boundary between government forest and individual pasture land (Gyamtsho, 2002; Norbu, 2002). Our survey shows that in Bhutan, the establishment of the parks did not have any effect on cattle migration (Table 5). However, this may not pose a serious threat, since Gyamtsho (2002) and Roder (2002) concluded that moderate grazing is stimulatory and beneficial to range land ecosystems, especially in the alpine and mid-alpine region (Gyamtsho, 2002; Roder, 2002). 


\section{Conservation Policy and Human-Wildlife Conflict}

Wildlife depredation on crops and domestic livestock is a widespread problem in developing countries, but many recent studies have shown that it appears to be more prevalent in the Himalayas (Mukherjee \& Board, 2004; Rao et al., 2002; Wang, Curtis, et al., 2006).

Wildlife depredation on crops and domestic livestock in Bhutan is felt a threatening problem in remote communities. Between one and four family members invest at least 4 months a year on average in warding off wild animals (Table 9). During this study, the visit to the JDNP was marked by such incidents. Over two nights, a snow leopard killed a bull and a mule and injured another bull. At the same time, a bear attacked the poultry shed of a household and destroyed all the animals. These incidents appear to be daily occurrences for those communities in and around the park areas.

Compensation appears to be either inadequate or nonexistent. Compensation is only granted for livestock that is killed by endangered species, such as the snow leopard and the tiger. No compensation is paid for crops that are damaged or for livestock killed by other predators. Interviews with local people and the park officials reveal that there is no institutional funding mechanism in place. The present compensation scheme is funded entirely by private donations from a foreign individual, and the administrative procedures appear to be complicated and lengthy. ${ }^{2}$ It seems as though the compensation scheme is a temporary scheme designed to sway local communities and to earn credibility in the initial stage of implementing conservation rules and regulations. This could backfire if the government later adopts a more callous attitude (Rao et al., 2002; Sekhar, 2003), possibly leading to retaliatory action against the predators. Another related consequence has been observed in a recent study of rural-urban migration conducted by the Ministry of Agriculture. About $3 \%$ of the rural-urban drift was attributed to crop damage by wild animals (RGoB, 2005), and unless there is a structural solution, rural-urban drift might intensify in the future. In reality, livestock depredation and crop damage by wildlife are two areas of concern that are now emerging as the main issue and problem encountered by the local communities throughout Bhutan (RGoB, 2002). Likewise, it appears that similar problems are common to more countries covered by recent studies in the Himalayan region (Mukherjee \& Board, 2004; Rao et al., 2002).

\section{Conservation as a Basis for Income Generation}

The conservation efforts have been promoted as a way of addressing the needs of the local communities to earn a livelihood and encouraging sustainable practices (Arjunan et al., 2006). The benefits could result either from the direct investment made by the government in the protected areas or from the survival of some forest products as a result of conservation efforts. The direct benefits come from investments 
through ICDP activities, development services, and the employment opportunities provided by the park management.

Harvest of exotic mushrooms. Another important but latent benefit to local communities is the liberalization of harvesting of high-altitude mushrooms, Cordyceps and Matsutake Tricholoma, which grow in pine forests in both the parks covered by the study. The harvesting of Cordyceps was banned until 2004, but controlled harvesting has now been introduced (Namgyel, 2005). According to the Ministry of Agriculture's marketing division, the average price of a kilogram of dry Cordyceps at auction during 2004/2005 was US\$1,194. During a visit by the first author to one of the auction yards in JDNP in 2005, the highest price achieved was US\$1,860 per kilogram. The harvesting of Masutake is a community-managed activity, but its success is hampered by poor access by road, the perishable nature of the crop, and dependence on foreign markets. The average farm-gate price in 2005 was US $\$ 10$ per kilogram. The local communities have benefited from sales to local customers. More recently in 2008, permits for Cordyceps were greatly expanded, which could potentially lead to greater competition and reduced volume for area residents.

Employment. Employment opportunities for local communities appear to be another incentive for better participation in nature conservation. Community participation in conservation management is considered important for generating local support (Maroney, 2005; Sekhar, 2003; Ylhaisi, 2003). Yet the involvement of local residents in park management is often typically low in developing countries (Colchester, 2004). However, this study shows that the participation of communities is high, which is a result of the ICDP program. The park management employs local people as guards, caretakers, or local information officers on a temporary basis. But we see that most employment is on the lowest ranks in the management hierarchy, and the people concerned will have little influence on management decisions in the parks. This is a result of the lack of proper modern education. But this situation is likely to improve in due course, as more local leaders are expected to be appointed once the government's decentralization program becomes fully operational (RGoB, 2002).

\section{Conclusions}

Returning to the research questions, our conclusion is that the strong conservation policy stance of the government reflects a top-down approach and is not balanced as it is disproportionately skewed toward the conservation of nature. This reflects the influence of donor countries and their policies (this has recently been discussed in Bhutan; see Swiss Development Cooperation and Social Forestry Division Department of Forest [RGoB], 2008). As such, it contradicts the overall sustainable development 
policy of Bhutan, which emphasizes a balance between environmental conservation, cultural conservation, economic progress, and good governance (RGoB, 1996; see also Rinzin, 2006; Rinzin, Vermeulen, et al., 2007). Buddhism is important in shaping positive attitudes toward nature conservation among local people, although less important than originally expected given that this study was carried out in rural communities. There is full support for nature conservation, and people are satisfied with their way of life. However, people are disgruntled at the change in ownership of land and with having to live within the constraints of new conservation rules and regulations. The conservation management program, the ICDP activities, had little impact on easing the tension between local communities and wildlife. The wildlife depredation of crops and domestic livestock is detrimental to the local economy as these are the only sources of livelihood. The long-term success of the conservation goals cannot be achieved unless an appropriate compensation scheme is worked out. A likely consequence if this problem is not resolved is an increase in the urban population as it could lead to depopulation of rural areas and abandonment of agriculture, which means those people who belong to farming community are forced to leave their homes.

The government also did not pay much attention regarding the impacts on the traditional norms of the local people while implementing the nature conservation rules. The traditional norms of resource management were ignored, and new rules were introduced. The restrictions on the use of nontimber products also appear to have affected the production of traditional local arts and crafts.

The idea of conservation is not new to the Bhutanese people. It is ingrained in their traditional way of life. Policy choices should capitalize on this existing potential by providing conservation education rather than weakening it by imposing new rules and regulations, thereby depriving people of the sense of traditional community ownership.

\section{Notes}

1. With the establishment of another protected area in the north in 2008 , more than $50 \%$ of Bhutan is in some form of conservation status.

2. Source: Interviews with the park managers.

\section{References}

Abakerli, S. (2001). A critique of development and conservation policies in environmentally sensitive region in Brazil. Geoforum, 32, 551-565.

Arjunan, M., Holmes, C., Puyravaud, J.-P., \& Davidar, P. (2006). Do developmental initiatives influence local attitudes towards conservation? A case study from the Kalakad-Mundanthurai Tiger Reserve, India. Environment and Management, 79, 188-197.

Buergin, R. (2003). Shifting frames for local people and forest in a global heritage: The Thung Yai Naresuan Wildlife Sanctuary in the context of Thailand's globalisation and modernization. Geoforum, 34, 375-393. 
Christopoulou, O. G., \& Tsachalidis, E. (2004). Conservation policies for protected areas (wetlands) in Greece: A survey of local residents' attitude. Water, Air and Soil Pollution Focus, 4, 455-457.

Colchester, M. (2004). Conservation and indigenous peoples. Environmental Science \& Policy, 7, 145-153.

Central Statistical Organisation. (2005). Statistical Year Book of Bhutan. Thimphu, Bhutan: N.S. Bureau, TN Printing Press.

Dear, C. E., \& Myers O. E., Jr. (2005). Conflicting understandings of wilderness and subsistence in Alaskan national parks. Society and Natural Resources, 18, 821-837.

Fearnside, P. M. (2003). Conservation policy in Brazilian Amazonia: Understanding the dilemmas. World Development, 31, 757-779.

Fraga, J. (2006). Local perspective in conservation polities: The case of the Ria Lagartos Biosphere Reserve, Yucatan, Mexico. Landscape and Urban Planning, 74, 285-295.

Gyamtsho, P. (1996). Assessment of the condition and potential for improvement on high altitude rangelands of Bhutan (ETH No. 11726). Unpublished doctoral dissertation, Swiss Federal Institute of Technology, Zurich.

Gyamtsho, P. (2002). Condition and potential for improvement of high altitude rangelands. Journal of Bhutan Studies, 7, 82-98.

Huber, O. (2001). Conservation and environmental concerns in the Venezuelan Amazon. Biodiversity and Conservation, 10, 1627-1643.

Kamppinen, M., \& Walls, M. (1999). Integrating biodiversity into decision making. Biodiversity and Conservation, 8(1), 7-16.

Lin, M. Y., Zhang, S. S., \& Chen, Y. (2005). Distance-to-target weighting in life cycle impact assessment based on Chinese environmental policy for the period 1995-2005. International Journal of Life Cycle Assessment, 10, 393-398.

Maikhuri, R. K., Nautiyal, S., Rao, K. S., \& Saxena, K. G. (2001). Conservation policy-people conflict: A case study from Nanda Devi Biosphere Reserve (a World Heritage Site), India. Forest Policy and Economics, 2, 355-365.

Maroney, R. L. (2005). Conservation of argali Ovis ammon in western Mongolia and the Altai-Sayan. Biological Conservation, 121, 231-241.

McLean, J., \& Stræde, S. (2003). Conservation, relocation, and the paradigms of park and people management-A case study of Padampur villages and the Royal Chitwan National Park, Nepal. Society and Natural Resources, 16, 509-526.

Metha, J. N., \& Heinen, J. T. (2001). Does community-based conservation shape favourable attitudes among locals? An empirical study from Nepal. Environmental Management, 28, 165-177.

Mukherjee, A., \& Board, C. K. (2004). Integrated approach to conservation of Gir National Park: The last refuge of Asiatic lions, India. Biodiversity and Conservation, 13, 2165-2182.

Muradin, R. (2002). Greening trade and investment: Environmental protection without protectionism. Environment and Planning A, 34, 1319-1320.

Namgyel, P. (2005). Forest policy and income opportunities from NTFP commercialisation in Bhutan. Reading, UK: University of Reading.

Natori, Y., Fukui, W., \& Hikasa, M. (2005). Empowering nature conservation in Japanese rural areas: A planning strategy integrating visual and biological landscape perspectives. International Journal of Landscape and Urban Planning, 70, 315-324.

Nelissen, N. J. M., Van Der Straaten, J., \& Klinkers, L. (1998). Classics in environmental studies: Overview of classic texts in environmental studies. Utrecht, Netherlands: International Books.

Norbu, L. (2002). Grazing management in broadleaf forests. Journal of Bhutan Studies, 7, 99-129.

Palmer, M., \& Bisset, E. (1989). Worlds of difference. London: Blackie.

Pullin, A. S., \& Knight, T. M. (2003). Support for decision making in conservation practice: An evidencebased approach. Nature Conservation, 11(2), 83-90.

Rao, K. S., Maikhuri, R. K., Nautiyal, S., \& Saxena, K. G. (2002). Crop damage and livestock depredation by wildlife: A case study from Nanda Devi Biosphere Reserve, India. Journal of Environmental Management, 66, 317-327. 
Rao, K. S., Nautiyal, S., Maikhuri, R. K., \& Saxena, K. G. (2003). Local people's knowledge, aptitude and perceptions of planning and management issues in Nanda Devi Biosphere Reserve, India. Environmental Management, 31, 168-181.

Rinzin, C. (2006). On the middle path: The social basis for sustainable development in Bhutan. Utrecht, Netherlands: Geographical Studies.

Rinzin, C., ten Velthuis, D. N., \& Vermeulen, W. J. V. (2007). The "successful failure" of the sustainable development agreement between the Netherlands and Bhutan. Sustainable Development, 15(6), 382-396.

Rinzin, C., Vermeulen, W. J. V., \& Glasbergen, P. (2007a). Eco-tourism as a mechanism for sustainable development: The case of Bhutan. Environmental Sciences, 4(2), 109-125.

Rinzin, C., Vermeulen, W. J. V., \& Glasbergen, P. (2007b). Public perceptions of Bhutan's approach to sustainable development in practice. Sustainable Development, 15(1), 52-68.

Roder, W. (2002). Grazing management of temperate grassland and fallows. Journal of Bhutan Studies, 7, 44-60.

Roper, M. (2000). On the way to a better state? The role of NGOs in the planning and implementation of protected areas in Brazil. Geojournal, 52(1), 61-69.

Royal Government of Bhutan, Planning Commission. (1996). Eighth five year plan (1997-2002). Bangkok, Thailand: Keen Publishing.

Royal Government of Bhutan. (2001). Thrumsingla National Park conservation management plan. Thimphu, Bhutan: Nature Conservation Division, Ministry of Agriculture.

Royal Government of Bhutan, Nature Conservation Division. (2002). Biodiversity action plan for Bhutan 2002. Bangkok, Thailand: Keen Publishing.

Royal Government of Bhutan. (2002). Geog Yargay Tshogchhung Chathrim, 2002. Thimphu, Bhutan: Ministry of Home Affairs.

Royal Government of Bhutan. (2003). Vision and strategy for the Nature Conservation Division 2003. Thimphu, Bhutan: Ministry of Agriculture, Department of Forestry Services, Kuensel Corporation.

Royal Government of Bhutan. (2004). Walking the extra mile: Selected RNR statistics. Thimphu, Bhutan: Policy and Planning Division, Ministry of Agriculture.

Royal Government of Bhutan. (2005a). Jigme Dorji National Park Conservation Management Plan 20052007. Thimpu, Bhutan: Nature Conservation Division, Department of Forests, Ministry of Agriculture.

Royal Government of Bhutan. (2005b). Rural-urban migration in Bhutan. Thimphu, Bhutan: Policy and Planning Division, Ministry of Agriculture.

Sekhar, N. U. (2003). Local people's attitudes towards conservation and wildlife tourism around Sariska Tiger Reserve, India. Journal of Environmental Management, 69, 339-347.

Silva, L. d. (1992). The hills wherein my soul delights. In M. Batchelor \& K. Brown (Eds.), Buddhism and ecology (pp. 18-30). New Delhi, India: Motilal Banarsdass.

Slattery, D. (2002). Resistance to development at Wilsons Promontory National Park (Victoria, Australia). Society and Natural Resources, 15, 563-580.

Soto, B., Munthali, S. M., \& Breen, C. (2001). Perceptions of the forestry and wildlife policy by the local communities living in the Maputo Elephant Reserve, Mozambique. Biodiversity and Conservation, 10, 1723-1738.

Swiss Development Cooperation and Social Forestry Division Department of Forest (RGoB). (2008, September 3-7). Report on the International Workshop on Forests, Landscape and Governance: The roles of local communities, development projects, the state and other stakeholders. Workshop organized by Intercooperation and the Swiss Federal Office for the Environment, Punakha, Bhutan.

Valutis, L., \& Mullen, R. (2000). The Nature Conservancy's approach to prioritising conservation action. Environmental Science \& Policy, 3, 341-346.

Wang, S. W., Curtis, P. D., \& Lassoie, J. P. (2006). Farmer perceptions of crop damage by wildlife in Jigme Singye Wangchuck National Park, Bhutan. Wildlife Society Bulletin, 34, 359-365.

Wang, S. W., Lassoie, J. P., \& Curtis, P. D. (2006). Farmer attitudes towards conservation in Jigme Singye Wangchuck National Park, Bhutan. Environmental Conservation, 33, 148-156. 
Wangchuk, S. (2001, Summer). Local resource management institutions: A case study on Sokshing Management. Journal of Bhutan Studies, 3(1), 1-47.

Wangchuk, S. (2002). Grazing management in national parks and protected areas: Science, socioeconomic and legislation (tenure). Journal of Bhutan Studies, 7, 61-81.

White, R. (1994). Preface. In B. R. Allenby \& D. J. Richards (Eds.), The greening of industrial ecosystems. Washington, DC: National Academy Press.

World Wildlife Fund. (2004). How effective are the protected areas? Report prepared for the Seventh Conference of Parties of the Convention on Biological Diversity, Putra World Trade Centre, Kuala Lumpur, Malaysia.

Yang, X., \& Xu, M. (2003). Biodiversity conservation in Changbai Mountain Biosphere Reserve, Northeastern China: Status, problem, and strategy. Biodiversity and Conservation, 12, 883-903.

Ylhaisi, J. (2003). Forest privatisation and the role of community in forests and nature protection in Tanzania. Environmental Science \& Policy, 6, 279-290.

Chhewang Rinzin, $\mathrm{PhD}$, is a researcher and lecturer at the Royal Institute of Management, part of the Royal University of Bhutan. E-mail: chhewang_rinzin@rim.edu.bt

Walter J. V. Vermeulen, $\mathrm{PhD}$, is an associate professor and program leader of the international prestige master Sustainable Development at Utrecht University. E-mail: w.vermeulen@geo.uu.nl

Martin J. Wassen, $\mathrm{PhD}$, is a professor in environmental science and head of the Department of Innovation and Environmental Sciences at the Faculty of Geosciences of Utrecht University. E-mail: m.wassen@geo.uu.nl

Pieter Glasbergen, $\mathrm{PhD}$, is a professor in environmental studies and policy at the Department of Innovation and Environmental Sciences at the Faculty of Geosciences of Utrecht University. E-mail: p.glasbergen@geo.uu.nl 